\title{
The Computational Science and Engineering (CS\&E) Program at Purdue University
}

\author{
Thomas Downar and Tomasz Kozlowski \\ School of Nuclear Engineering, \\ Purdue University, \\ West Lafayette, Indiana 47907-1290 \\ U.S.A \\ \{downer, tomasz\}@ecn.purdue.edu \\ http://www. cse.purdue.edu
}

\begin{abstract}
Purdue University has established an interdisciplinary graduate degree program in Computational Science and Engineering (CS\&E). Both M.S. and Ph.D. degrees are offered. The program provides students with the opportunity to study a specific science or engineering discipline along with computing in a multi-disciplinary environment. The aim of the program is to produce a student who has learned how to integrate computing with another scientific or engineering discipline.
\end{abstract}

\section{Introduction}

In the Fall of 1995, Professors John Rice and Elias Houstis from the Computer Science Department at Purdue created the Computational Science and Engineering (CS\&E) interdisciplinary graduate specialization program. Since 2000, Professor Tom Downar from the Schools of Engineering has been the director of CS\&E which now has 80 students enrolled from 17 participating departments. Detailed information about the Purdue CS\&E program is available at www.cse.purdue.edu.

The CS\&E program is open to students admitted to a home department but interested in performing research at either the M.S. or Ph.D. level with a computational science and engineering specialization. The student's participation in the program is indicated on his/her transcript as a specialization depending on the student's school:

- Agriculture: COMPUTATIONAL SCIENCE

- Engineering: COMPUTATIONAL ENGINEERING

- Liberal Arts: COMPUTATIONAL SCIENCE

- Pharmacy: COMPUTATIONAL SCIENCE

- Science: COMPUTATIONAL SCIENCE

Seventeen departments offer CS\&E specializations which are listed in Table 1 together with their Heads. Each department has a representative on the CS\&E graduate committee which administers the CS\&E program. 
Table 1. CS\&E participating department list

\begin{tabular}{|l|l|}
\hline DEPARTMMENT & NAME \\
\hline AERO \& ASTRO ENGINEERING & T. N. Farris \\
\hline AGRICULTURAL ECONOMICS & Sally Thompson \\
\hline AGRONOMY & Craig A. Beyrouty \\
\hline BIOLOGICAL SCIENCES & David Asai \\
\hline CHEMISTRY & Ian Rothwell \\
\hline COMPUTER SCIENCES & Susanne Hambrusch \\
\hline EARTH \& ATMOSPHERIC SCIENCES & Harshvardhan \\
\hline ELECT \& COMP ENGINEERING & Leah Jemieson (Interim Head) \\
\hline FOOD SCIENCE & P. Nelson \\
\hline INDUS \& PHYS PHARMACY & Stephen R. Byrn \\
\hline MATHEMATICS & Leonard Lipshitz \\
\hline MECHANICAL ENGINEERING & E. Daniel Hirleman \\
\hline $\begin{array}{l}\text { MED CHEMISTRY \& MOLECULAR } \\
\text { PHARMACOLOGY }\end{array}$ & Richard F. Borch \\
\hline NUCLEAR ENGINEERING & Lefteri H. Tsoukalas \\
\hline PHARMACY PRACTICE & Steven R. Abel \\
\hline PHYSICS & Andrew Hirsch \\
\hline PSYCHOLOGICAL SCIENCES & Thomas Berndt \\
\hline STATISTICS & Mary Ellen Bock \\
\hline
\end{tabular}

Funding for the CS\&E program is provided by the Provost in the form of a reoccurring grant which is used to fund the salary of the CS\&E program coordinator and provide for incidental expenses such as travel funds and honorarium for CS\&E seminar speakers.

CS\&E students are expected to have a strong interest in computation and its application to science and engineering. Their undergraduate training is expected to have given them a strong foundation in several areas of science, engineering, and computing. It is, however, likely that many will not have both the interdisciplinary breadth and depth needed for the CS\&E Program. Some students will fill in their deficiencies by taking some background courses and others will exploit their talents to catch up on missing background while taking graduate courses. The course CS 501 is specifically designed to allow students who did not major in computer science or computer engineering to learn quickly key concepts from upper level undergraduate computer science courses.

Advising CS\&E students is handled by the CS\&E staff (for routine matters), the Advisory Committee (for education program matters), and the major professor (for research direction). Documents are available to guide the students about requirements 
and procedures. The routine registrar and graduate school forms are signed only by the CS\&E staff unless agreed otherwise.

The non-educational support of a CS\&E student is normally provided by the home department. In some cases (e.g., Ph.D. fellows) this support may be given by the sponsoring department. Examples of such support include:

- Business office support for financial matters,

- Advice and support for matters not directly related to education, e.g., disciplinary actions, visa problems,

- Office space, provided on the same basis as for regular students in the home department,

- Supplies, computing, copying, and similar items, provided on the same basis as for regular students in the home department.

The student enrollment in CS\&E is shown in Figure 1.

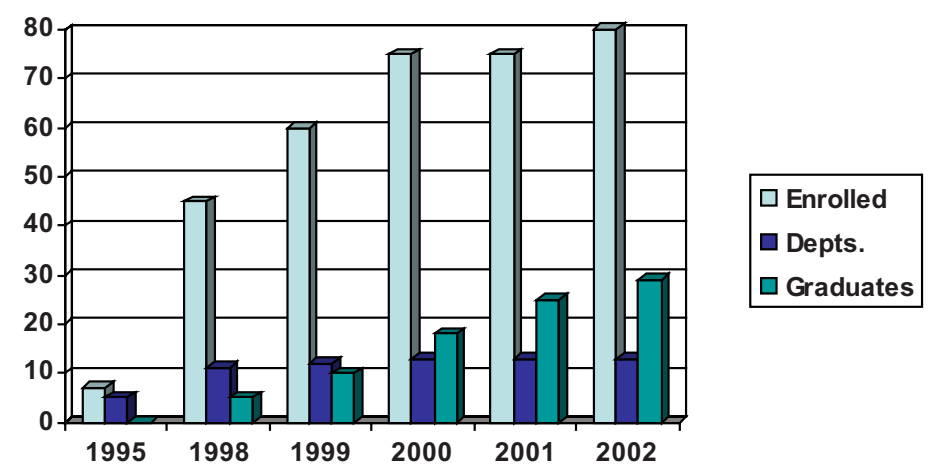

Fig. 1. Student enrolment in CS\&E program

\section{Admission to CS\&E Program}

Admission to CS\&E program is administered through the student's home department. The Graduate School requires a Bachelor's degree and an overall grade point average (GPA) of at least 3.00/4 $(\mathrm{A}=4, \mathrm{~B}=3, \mathrm{C}=2, \mathrm{D}=1, \mathrm{~F}=0)$. The Graduate School also requires non-native speakers of English to obtain a score of at least 550 on the test of English as a Foreign Language (TOEFL). However, the home department might have higher TOEFL requirement.

There are two basic cases for admission to CS\&E program:

1. A student admitted to a participating department at Purdue applies to the CS\&E program. The CS\&E Admissions Committee reviews the application and decides on the admission.

2. An applicant not at Purdue can apply directly to the home department requesting to be considered for the CS\&E specialization or CS\&E program. The CS\&E Ad- 
missions Committee reviews these applications and makes recommendations to the home department for final approval. The home department notifies the applicant of the result.

\section{CS\&E Curriculum}

The CS\&E curriculum is defined through the CS\&E core courses and CS\&E relevant courses specified by the participating departments. The basic graduate training in computational science and engineering is provided by the core courses listed below:

- INTRODUCTION TO CS\&E

- CS 501: Introduction to CS\&E

- COMPUTATIONAL MATHEMATICS

- CS 514: Numerical Analysis

- CS 515: Numerical Analysis of Linear Systems

- ME 581: Numerical Methods

- HIGH PERFORMANCE COMPUTING

- CS 525: Parallel and Vector Computing

- EE 563: Programming Parallel Machines

- INTELLIGENT COMPUTING

- CS 572: Heuristic Problem Solving

- EE 570: Programming Techniques for Artificial Intelligence

- SCIENTIFIC VISUALIZATION

- CS 530: Scientific Visualization

- EE 628: Computer Graphic Simulations and Visualization

- COMPUTATIONAL OPTIMIZATION

- CS 520: Computational Methods in Analysis

- EE 580: Computational Optimization

- IE 535: Linear Programming

- MA 521: Computational optimization

The CS 501 course was created specifically for the CS\&E program to help students acquire the background for the other core courses. The specific objectives of CS 501 are to familiarize students from various disciplines in the science of problem solving. This includes basic computational tools (e.g. MATLAB, Mathematica, etc), computational kernels of important problems and core techniques for solving the problems. CS 501 emphasizes computer simulations as an important design tool and the role of high performance computing in large scale "Grand Challenge" type problems.

In addition to the core courses, the CS\&E Program maintains a list of CS\&Erelevant courses offered by the participating departments. These courses have a substantial computational component or relevance and are accessible and of potential interest to students from other departments. This list provides guidance in selecting CS\&E courses for plans of study. 


\subsection{The CS\&E Specialization for the M.S. Degree}

The M.S. specialization of the CS\&E Program may consist entirely of courses or of course work plus a project or M.S. thesis up to nine hours. At least thirty hours of credit are required for the degree, the equivalent of 10 normal courses. The plan of study must contain total three courses in the CS\&E field of which at least two are CS\&E core courses from different groups. No M.S. Degree examination is required. The plan of study is worked out by a student and advisor; it must be approved by the graduate committees of both the home department and CS\&E program. Further details on the M.S. requirements are determined by the participating home departments.

\subsection{The CS\&E Specialization in the Ph.D. Degree}

The Ph.D. plan of study is determined by the student and the major professor to prepare the student for research. The plan of study must also meet Graduate School requirements and be approved by the graduate committees of both the CS\&E Program and the home department. The graduate committee of the CS\&E Program expects about one third of the courses on the plan of study to be in the computing field. The following Ph.D. degree requirements are expected:

- The plan of study must contain at least four CS\&E courses, including two CS\&E core courses from different groups.

- The CS\&E program does not require any general examination.

- GPA requirements: No course with a grade of $\mathrm{C}$ or lower may appear on the plan of study. The GPA in CS\&E courses must be at least 3.25. The overall GPA in graduate courses on the plan of study must be at least 3.25 .

- Qualifying examinations: Students are not required to pass any CS\&E examination unless the home department or the Ph.D. advisory committee requests it.

- Preliminary examinations: These are given by the Ph.D advisory committee.

- The Chair of the Ph.D. advisory committee must be a member of the CS\&E program faculty. The committee must contain one member from the home department and one CS\&E faculty member not in the home department.

Further details on the Ph.D requirements for each participating department are provided in the CS\&E graduate manual.

\subsection{CS\&E Specialization Requirements from Participating Departments}

Each participating department also specifies requirements for their individual schools that the student must satisfy. As an example, details of the program requirements from the Aeronautics and Astronautics Engineering School are provided below.

The specialization in Computational Engineering is available to students in the School of Aeronautics \& Astronautics wishing to develop a strong background in computational methods of engineering analysis and design. The CS\&E specialization 
is available to both M.S. and Ph.D. students. M.S. students may take either the thesis or non-thesis option.

The CS\&E specialization for MS-A\&AE. The student must choose a major and a minor area from among the approved School list. The CS\&E specialization is available as a minor area under the interdisciplinary area option.

Minimum requirements for the thesis option are:

- Completion of twenty-one credit hours of graduate course work on an approved plan of study, which must include nine credit hours in the major area, six hours in the minor area and six hours in mathematics. Six of the CS\&E credit hours must be taken in courses outside the major area.

- Attainment of a minimum cumulative index of 3.0 for graduation.

- Completion of nine credit hours of thesis-related research. Completion of a thesis to the satisfaction of the student's examination committee in compliance with the School and University format requirements.

- Public oral presentation of the research results.

- Passage of a closed oral examination by the examination committee.

Minimum requirements for the non-thesis option are:

- Completion of thirty credit hours of graduate course work on an approved plan of study, which must include twelve credit hours in the major area, six hours in the minor area and six hours in mathematics. Six of the CS\&E credit hours must be taken in courses outside the major area.

- Attainment of a minimum cumulative index of 3.0 for graduation.

- Certification of the degree by the student's examination committee.

The CS\&E specialization for Ph.D.-A\&AE. The student must choose a major and a minor area from among the approved School list. The CS\&E specialization is not considered a major or minor area for the Ph.D. degree program.

Minimum requirements for the Ph.D. degree are:

- Completion of eighteen credit hours of graduate course work beyond the M.S. degree on an approved plan of study.

- Attainment of an index of 3.0 for all courses on an approved plan of study.

- Successful completion of qualifying examinations in the major and minor areas and in mathematics. In lieu of the minor area qualifying exam, six hours of course work in the minor area may be taken, subject to obtaining a grade of "B" or better. Courses used to fulfill the minor area requirement may not be counted toward satisfaction of the CS\&E course requirements.

- Successful completion of an oral preliminary examination given by the student's examination committee.

- Completion of a thesis to the satisfaction of the student's examination committee in compliance with the School and University format requirements.

- Public oral presentation of the research results.

- Passage of a closed oral examination by the examination committee. 


\section{CS\&E Seminar Program and Fellowships}

Another feature of the CS\&E program is the seminar program. Students are required to attend $3 \mathrm{CS} \& \mathrm{E}$ seminars each semester. An example of the seminars from years 2002-2003 is shown in Table 2 below.

Table 2. Representative CS\&E seminary speakers

\begin{tabular}{|l|l|}
\hline Speaker & Title of Talk \\
\hline $\begin{array}{l}\text { Gene Golub, Computer Science, } \\
\text { Stanford University }\end{array}$ & $\begin{array}{l}\text { Solution of Non-Symmetric, Real } \\
\text { Positive Linear Systems }\end{array}$ \\
\hline $\begin{array}{l}\text { Frank Tip, IBM TJ Watson Research } \\
\text { Center }\end{array}$ & $\begin{array}{l}\text { Practical Extraction Techniques for } \\
\text { Java }\end{array}$ \\
\hline $\begin{array}{l}\text { Hironori Kasahara, Waseda } \\
\text { University, Tokyo, Japan }\end{array}$ & $\begin{array}{l}\text { Multigrain Parallel Processing in } \\
\text { Japanese Millennium Project IT21 } \\
\text { "Advanced Parallelizing Compiler" }\end{array}$ \\
\hline $\begin{array}{l}\text { Ricardo Bianchini, Rudger } \\
\text { University }\end{array}$ & $\begin{array}{l}\text { Application Transformations for } \\
\text { Energy-Efficient Device Control }\end{array}$ \\
\hline Yousef Saad, University of Minnesita & $\begin{array}{l}\text { Parallel Algebraic Recursive } \\
\text { Multilevel Solvers (pARMS) }\end{array}$ \\
\hline $\begin{array}{l}\text { Steven F. Ashby, Lawrence } \\
\text { Livermore National Laboratory }\end{array}$ & $\begin{array}{l}\text { Terascale Scientific Simulation } \\
\text { Ed Angel, University of New Mexico }\end{array}$ \\
\hline $\begin{array}{l}\text { Ahmed K. Noor, NASA Langley } \\
\text { Research Center }\end{array}$ & $\begin{array}{l}\text { Perspectives on Multiscale Modeling, } \\
\text { Simulation and Visualization }\end{array}$ \\
\hline Vince Mousseau, Los Alamos & $\begin{array}{l}\text { Physics-Based Preconditioned } \\
\text { Jacobian-free Newton-Krylov } \\
\text { Solutions }\end{array}$ \\
\hline Li-Shi Luo, ICASE & $\begin{array}{l}\text { Lattice Gas and Lattice Boltzmann } \\
\text { Methods: Past, Present, and Future }\end{array}$ \\
\hline
\end{tabular}

An additional service provided by CS\&E is to award fellowships and scholarships to the top CS\&E students. Since 1995, CS\&E has awarded 30 fellowships to CS\&E students, to include 5 U.S. Department of Education GAANN (Graduate Education in Areas of National Need) Ph.D. Fellowships.

\section{Summary}

Future plans for CS\&E include the development of a second introductory core course, CS 502 and closer collaboration with other computational educational programs at Purdue. Next year, Purdue will begin a Computational Life Sciences program and plans are underway to begin an Information Systems Science and Engineering graduate educational program. Plans are to administer all Purdue interdisciplinary computational educational programs as part of the Computer Research Institute at Purdue. 


\section{References}

1. Graduate Policies and Procedures Manual, Purdue University, 2003.

http: / /www. purdue. edu/GradSchool/faculty/resources/policies.html

2. Computer Science and Engineering Manual, Purdue University, 2003.

http: / /www.cse.purdue.edu/

3. Computing Research Institute, Purdue University, 2003.

http: / /www.cri.purdue.edu/ 